\title{
TRPV1, Nrf2, and COVID-19: Could Oxytocin Have a Beneficial Role to Play?
}

\author{
Phuoc-Tan Diep \\ University Hospitals of Morecambe Bay NHS Foundation Trust, Kendal, UK
}

\section{Dear Editor,}

Bousquet et al. [1] have elegantly and very informatively linked TRPV1, Nrf2, nutrients, and COVID-19: "rapid desensitization of TRAP1/TRPV1 by some ingredients in foods could reduce symptom severity and provide new therapeutic strategies."

I would like to strengthen their links and proffer a peptide that could be important to their hypothesis: oxytocin.

Oxytocin is known for its function in labour and lactation and as the "love" hormone. However, it has numerous other actions and these actions provide additional supportive links and data. Oxytocin increases Nrf2 [2]. Oxytocin is a TRPV1 agonist and can desensitize the receptor [3]. Oxytocin also reduces TRPV1 activity indirectly via the vasopressin 1a receptor [4]. In addition, oxytocin can inhibit TRPV1 presynaptically [5]. In turn, thermal stimulation of TRPV1 can release oxytocin [6]. In terms of viral pathology, viruses can up-regulate TRPV1 [7], while down-regulating oxytocin receptors [8].

It is interesting to note that many of the "Nrf2-, TRPA1-, and TRPV1-interacting nutrients" (see Table 1 Bousquet et al. [1]) can also increase oxytocin or improve its function: Lactobacillus [9], quercetin [10], zinc [11], vitamin C [12], and vitamin D [13]. In another paper, Bousquet et al. [14] note that Nrf2-interacting nutrients also act on "mTOR, mammalian target of rapamycin;
$\operatorname{PPAR} \gamma$, peroxisome proliferator-activated receptor; $\mathrm{NF \kappa B}$, nuclear factor kappa B; ERK, extracellular signalregulated kinases; and eIF2 $\alpha$, elongation initiation factor $2 a$." Oxytocin also acts on these (in animal and in vitro studies): mTOR [15], PPAR $\gamma$ [16], NFkB [17], ERK [18], and eIF2 $\alpha$ [19]. Therefore, the endogenous neurohormone, oxytocin, is capable of both inhibiting TRPV1 and increasing Nrf2, and modulating numerous other pathways. This adds to the complexity of the link between TRPV1 and Nrf2.

This also raises some questions and gaps in knowledge. Does oxytocin act as part of a nutrient-oxytocin-Nrf2 pathway or does it act in parallel? In addition, can oxytocin act synergistically with these nutrients?

Not surprisingly, oxytocin has already been proposed as a treatment for COVID-19 due to numerous anti-inflammatory properties [16], antioxidant properties [20], anti-diabetic properties $[21,22]$, cardioprotective properties [23], and even possible direct antiviral properties [24]. It is safe and easily administered intranasally [25].

I hope these additional links will advance the understanding of how TRPV1, Nrf2, and nutrients interact, and therefore, strengthen Bousquet's hypothesis and importantly, I hope this will lead to further research in this area and new therapeutic strategies.

Edited by: H.-U. Simon, Bern. 
Acknowledgment

I wish to thank Véronique de Kok for her help.

\section{Conflict of Interest Statement}

The author has no conflicts of interest to declare.

\section{Funding Sources}

The author has no funding to declare.

\section{Author Contributions}

Phuoc-Tan Diep contributed to conceptualization, methodology, and writing.

\section{References}

1 Bousquet J, Czarlewski W, Zuberbier T, Mullol J, Blain H, Cristol J-P, et al. Potential Interplay between Nrf2, TRPA1, and TRPV1 in nutrients for the control of COVID-19. Int Arch Allergy Immunol. 2021;182(4):324-38.

2 Cho SY, Kim AY, Kim J, Choi DH, Son ED, Shin DW. Oxytocin alleviates cellular senescence through oxytocin receptor-mediated extracellular signal-regulated kinase/Nrf2 signalling. Br J Dermatol. 2019 Dec;181(6): 1216-25.

3 Nersesyan Y, Demirkhanyan L, Cabezas-Bratesco D, Oakes V, Kusuda R, Dawson T, et al. Oxytocin modulates nociception as an agonist of pain-sensing TRPV1. Cell Rep. 2017 Nov;21(6):1681-91.

4 Han RT, Kim H-B, Kim Y-B, Choi K, Park GY, Lee PR, et al. Oxytocin produces thermal analgesia via vasopressin-1 a receptor by modulating TRPV1 and potassium conductance in the dorsal root ganglion neurons. Korean J Physiol Pharmacol. 2018;22(2):173.

5 Sun W, Zhou Q, Ba X, Feng X, Hu X, Cheng $\mathrm{X}$, et al. Oxytocin relieves neuropathic pain through GABA release and presynaptic TRPV1 inhibition in spinal cord. Front $\mathrm{Mol}$ Neurosci. 2018 Jul 17;11:248.

6 Sladek CD, Song Z, Stevens W. Thermal stimulation of vasopressin and oxytocin (VP/OT) release from explants of the hypothalamoneurohypophyseal system (HNS). FASEB J. 2012;26(S1):900-3900.3.

7 Omar S, Clarke R, Abdullah H, Brady C, Corry J, Winter $\mathrm{H}$, et al. Respiratory virus infection up-regulates TRPV1, TRPA1 and ASICS3 receptors on airway cells. PLoS One. 2017 Feb 10;12(2):e0171681.

8 Liu Y, Conboy I. Unexpected evolutionarily conserved rapid effects of viral infection on oxytocin receptor and TGF- $\beta / \mathrm{pS}$ mad3. Skelet Muscle. 2017 Dec;7(1):7.
9 Poutahidis T, Kearney SM, Levkovich T, Qi P, Varian BJ, Lakritz JR, et al. Microbial symbionts accelerate wound healing via the neuropeptide hormone oxytocin. PloS One. 2013 Oct 30;8(10):e78898

10 Jamei M, Sadeghi AA. Bisfenol effect of quercetin on cortisol and oxytocin levels, oxytocin receptor gene expression and morphometry of uterus in rats exposed to bisphenol A; 2016. Available from: http://vetdergikafkas.org/uploads/pdf/pdf_KVFD_1980.pdf.

11 Liu D, Seuthe AB, Ehrler OT, Zhang X, Wyttenbach T, Hsu JF, et al. Oxytocin-receptor binding: why divalent metals are essential. J Am Chem Soc. 2005 Feb 1;127(7):2024-5.

12 Luck MR, Jungclas B. The time-course of oxytocin secretion from cultured bovine granulosa cells, stimulated by ascorbate and catecholamines. J Endocrinol. 1988 Feb;116(2): 247-58.

13 Patrick RP, Ames BN. Vitamin D hormone regulates serotonin synthesis. Part 1: relevance for autism. FASEB J. 2014 Jun;28(6): 2398-413.

14 Bousquet J, Cristol JP, Czarlewski W, Anto JM, Martineau A, Haahtela T, et al. Nrf2-interacting nutrients and COVID-19: time for research to develop adaptation strategies. Clin Transl Allergy. 2020 Dec;10(1):58.

15 Klein BY, Tamir H, Hirschberg DL, Glickstein SB, Welch MG. Oxytocin modulates mTORC1 pathway in the gut. Biochem Biophys Res Commun. 2013 Mar;432(3):466-71.

16 Buemann B, Marazziti D, Uvnäs-Moberg K. Can intravenous oxytocin infusion counteract hyperinflammation in COVID-19 infected patients. World J Biol Psychiatry. 2021 May 28;22(5):387-98.
17 Khori V, Alizadeh AM, Khalighfard S, Heidarian Y, Khodayari H. Oxytocin effects on the inhibition of the NF- $\mathrm{KB} / \mathrm{miR} 195$ pathway in mice breast cancer. Peptides. 2018 Sep; 107:54-60.

18 Zhong M, Yang M, Sanborn BM. Extracellular signal-regulated kinase $1 / 2$ activation by myometrial oxytocin receptor involves Galpha(q)Gbetagamma and epidermal growth factor receptor tyrosine kinase activation. Endocrinol. 2003 Jul 1;144(7):2947-56.

19 Inoue T, Yamakage H, Tanaka M, Kusakabe T, Shimatsu A, Satoh-Asahara N. Oxytocin suppresses inflammatory responses induced by lipopolysaccharide through inhibition of the eIF-2-ATF4 pathway in mouse microglia. Cells. 2019 May 31;8(6):527.

20 Rashed LA, Hashem RM, Soliman HM. Oxytocin inhibits NADPH oxidase and P38 MAPK in cisplatin-induced nephrotoxicity. Biomed Pharmacother. 2011 Oct;65(7):47480.

21 Elabd S, Sabry I. Two birds with one stone: possible dual-role of oxytocin in the treatment of diabetes and osteoporosis. Front Endocrinol. 2015 Aug 10;6:121.

22 Diep P-T. Oxytocin may be superior to gliptins as a potential treatment for diabetic COVID-19 patients. SciMed. J.. 2021 Jan 16; $2: 106-7$.

23 Wang SC, Wang YF. Cardiovascular protective properties of oxytocin against COVID-19. Life Sci. 2021 Apr;270:119130.

24 Diep PT, Talash K, Kasabri V. Hypothesis: oxytocin is a direct COVID-19 antiviral. Med Hypotheses. 2020 Dec; 145:110329.

25 Quintana DS, Smerud KT, Andreassen OA, Djupesland PG. Evidence for intranasal oxytocin delivery to the brain: recent advances and future perspectives. Ther Deliv. $2018 \mathrm{Jul}$; 9(7):515-25. 